\title{
Anthós
}

$7-2012$

\section{Imperialistic Incentives}

Katherine Jensen

Portland State University

Follow this and additional works at: https://pdxscholar.library.pdx.edu/anthos

Dart of the United States History Commons

Let us know how access to this document benefits you.

\section{Recommended Citation}

Jensen, Katherine (2012) "Imperialistic Incentives," Anthós: Vol. 4: Iss. 1, Article 2. https://doi.org/10.15760/anthos.2012.19

This open access Article is distributed under the terms of the Creative Commons Attribution-NonCommercialShareAlike 4.0 International License (CC BY-NC-SA 4.0). All documents in PDXScholar should meet accessibility standards. If we can make this document more accessible to you, contact our team. 
Katherine Jensen

\section{Imperialistic Incentives}

Within this essay I will summarize author Andrew Wender Cohen’s 2010 article entitled “Smuggling, Globalization, and America’s Outward State, 1870-1909.” I will describe the structure of the article as three distinct sections with an introduction and conclusion and complete a deeper analysis of the function of each section on an individual basis. An investigation of the primary and especially secondary sources will help to put Cohen's article into context as part of a greater discussion between other historical scholars. A closer look into the relevance and fit of the sources/evidence used for Cohen's article will be complemented by a study of Cohen's authority within the historical field to determine if his argument is warranted. My conclusions about the article and the crux of Cohen's argument will be best presented by its parallels to Karen Yamashita’s Tropic of Orange; I will find several fundamental similarities between the two works that each emphasize the present day impacts of past cultural and economic relations both internationally and within the United States.

“Smuggling, Globalization, and America’s Outward State, 1870-1909” is an investigation into the effects of the United States' strict import taxes and tariffs on imported goods. Published as a historical article in The Journal of American History, the author's goal is to examine the various effects of these tariffs and explore how they impact our nation today. As the title indicates, the pro-tariff (or protectionist) attitude within the United States' federal government during the turn of the twentieth century not only augmented the smuggling of foreign goods into the country, but also catalyzed imperialistic international relations and the 
Jensen 2

establishment of the United States as an outward authority. The term "outward state” refers to the concentration of federal presence regarding external affairs, international conflicts, and the nation's borders. In this article Cohen addresses the notion that the United States' fixation on their outward state results in the negligence of fundamental domestic systems, also known as the "weak state theory" (Cohen 372, note 4). Protectionism, the core of a preoccupation with the outward state, is at its most basic level the rejection of globalization. Where most Americans desired foreign luxuries, protectionists worked to limit the amount of imports allowed into the country, creating a gap between the United States and other economic powers active in international trade. Regulation of the tariff provided an excuse for the United States to expand its territory into neighboring countries, but also exploited and contributed to deficiencies within the nation itself. The discrimination and stereotyping of people based on race, gender, religion, and economic class was highly prominent in customhouses and heightened with each occurrence of a minority’s involvement in a smuggling operation. Cohen’s argument concludes that although the overprotective nature of import tariffs may have created a strong authority on the country’s borders, the tariffs ultimately isolated the United States from globalization and sacrificed both domestic influence and equality in order to infringe upon foreign economies and territories.

The first section delves directly into one of the main concerns of the article: how the excessive corruption involved with smuggling demonstrates America’s weak domestic state. Here Cohen provides explanation to the previously mentioned "weak state theory" wherein the US is theorized to have a weak infrastructure and little domestic influence (Cohen 372, n.4). Internal affairs were overshadowed by enforcing smuggling regulations such that the country 
Jensen 3

“lacked a national system of labor standards, social insurance, and economic regulation” (Cohen 372). To demonstrate this absence, Cohen spends a significant portion of his article exposing the number of federal workers that actively participated in smuggling for their personal benefit. One of the most expansive examples in the text is a description of Robert Des Anges, a Deputy Collector who was paid handsomely for each package he admitted into the United States (378). The entire first section of the article is structured around examples of large-scale smuggling and corruption. This emphasizes the lack of control the United States had even within its own borders over federally employed workers. The sheer number of examples and citations Cohen has in the article serves as a convincing exhibition of the government's ignorance of domestic smuggling. This passage also serves as the beginning of an extended metaphor relating the tariffs as "high walls" that "separated America from the rest of the world", a wall "built around the nation's economy” (Cohen 373, 374).

Where the first body section of the article addresses America's weak domestic authority, the following section provides detailed information on America's concern with their rising Outward State. The extensive means by which trade was regulated as well as the steep incentives for customs agents to enforce severe penalties serves as evidence of the federal government’s concern with external affairs. Cohen describes how the Secret Service, “America’s sole national police force”, worked abroad tailing Americans who purchased high taxed goods and sought to bring them back to the United States (380). The use of the Secret Service and other forces abroad to prevent smuggling is the neglect and perversion of their purpose to protect the American people. Instead of using these resources for domestic security, federal agencies were used most avidly as an extension of the US into coastal waters or abroad in Europe, in other 
Jensen 4

words, for the expansion of America's Outward State (Cohen 380). These officers were very well paid and received moieties on goods successfully kept from being smuggled into the country. One of the most prominent officers, Benaiah Gustin Jayne, collected " $\$ 316,700$ in moieties (\$5.8 million today)” which incensed many citizens considering the “U.S. president earned only \$25,000 per year” (Cohen 382). By including this comparison Cohen offers another possible motive of the tariff: revenue. Under this regime protectionists passed the outrageous “Smuggling Act of 1886 [which] prescribed a maximum sentence of two years in prison, a $\$ 10,000$ fine, assessment of court costs, and payment of duties equal to twice the contraband's value” from which Canadian nutmeg worth \$1,236 inflicted five months in prison and \$2,326.16 in fines (382). Cohen concludes this section by reminding the reader that even with excessive border and external protection, the US failed in keeping most illegal imports out of the country. After exploring the United States' internal and external conflicts, the final section takes a closer look at the political facet to smuggling and tariffs. Cohen dedicates several paragraphs to a discussion of the political battles between protectionists and reductionists. The conservativism and sectionalism that derived from protectionist politicians led to "unequal relationships” (Cohen 386) within the United States and with other countries, obstruction of "the development of connections with a broader world” (Cohen 386), and the dehumanization and profiling of “women, Asians and Jews” (Cohen 396). Post-Civil War politics deepened American sectionalism by targeting southern slave owners as the principal smugglers in the nation (Cohen 386). Internationally, the tariff was often used as leverage to obtain foreign land for American military bases and custom houses (Cohen 386). The use of smuggling laws on foreign goods as justification for impeding international boundaries is crucial to understanding Cohen’s 
Jensen 5

association between trade tariffs and American imperialism. Despite this movement outward Cohen points out the restrictions on globalization and foreign relations caused by limitations on trade. The United States' willingness to venture outside its borders for federal gain and yet avoid the cultural interaction and diversification of international trade, demonstrates the country's imperialistic motivations when enforcing the tariffs. This argument is supported by the antiSemitic, racist, and sexist interactions occurring within the country that define the United States as a "xenophobic" (385, n.36) nation bias to a white, masculine, Christian population (Group Notes).

Cohen utilizes a remarkable amount and diversity of primary sources to support the historical foundation of his argument. A significant amount of his sources are from newspaper articles published during the article’s time frame from 1870-1909. The wide variety of newspapers including the New York Times, Brooklyn Eagle, New York Herald, Philadelphia Inquirer, and Washington Post helps to prevent bias by acknowledging various perspectives. Cohen specifically uses opposing points of view to provide his audience with a glimpse of how torn the nation really was; where the New York Times reported incidents of foreign and domestic smuggling, its rival, the New York Herald, targeted federal government and customhouse officials (371). The competing newspapers are two of Cohen's most common primary sources. To supplement these accounts, Cohen includes extensive government records from Report of the Secretary of the Treasury on the State of the Finances for the Year as well as various court cases and rulings. These archives provide reliable data to draw comparisons from and help track changes from year to year. An excellent addition to Cohen's primary sources is the use of memoirs and personal records from federal officials. One of the most cited memoirs is 
Defrauding the Government: True Tales of Smuggling, from the Notebook of a Confidential Agent of the United States Treasury written by William H. Theobald (Cohen 374, n.8). This memoir provides a unique insider look at the government officials' relationship to smuggling as part of their job and as individuals. Another valuable genre of evidence utilized by Cohen is that of illustrations. Out of the five illustrations included, four are from Harper's Weekly, an extremely popular "illustrated newspaper" in which "the stories and illustrations from the front lines were so detailed that Secretary of War Stanton once tried to suspend publication of the paper because the reports were aiding the enemy” during the Civil War (DuBois). The illustrations Cohen chose for his article help solidify some of his broadest claims: a depiction of the small-time customhouse militia contributes to the argument of maintaining a strong external border; two illustrations of inside a customhouse reveal the racism and harsh conditions; and a political cartoon demonstrates how popular and controversial the politics of import tariffs were during the late 1800's (Cohen). By including several genres of primary evidence Cohen is building a foundation off of which to launch his complex historical argument.

In the paragraphs where Cohen analyzes the above secondary sources he often references other authors and historians who have contributed to related disciplines. Eric Rauchway, Emily Rosenberg, and Walter LaFeber are undoubtedly influential on Cohen’s article. Eric Rauchway has completed extensive work on the history of globalization, and has even written a book on the "history of the United States in the context of global economic development” (Mead). Personally thanked by Cohen for his contributions to the article, Rauchway has a Ph.D. from Stanford University in History and currently teaches History at the University of California. Emily Rosenberg holds similar interests to Rauchway and focuses on "the history of U.S. 
economic and cultural expansion from the late nineteenth century to the present” (Rosenberg). Walter LaFeber is a retired Professor from Cornell University whom Cohen cites several times throughout the article concerning Globalization and the Gilded Age. LaFeber is "one of the nation's most distinguished scholars in the history of American Foreign Relations” and is quoted most often for his book The New Empire: An Interpretation of American Expansion 1860-1898 (“President's"). As the title indicates, LaFeber and Cohen share central ideas about imperialistic American expansion during the late 1800's which continues the trend of American economic expansion as a main subject for nearly all secondary sources (“President’s”). Other significant sources include Kristin Hoganson, a specialist on the "United States in world context, cultures of U.S. imperialism, globalization” (Hoganson), and Matthew Frye Jacobson, whose interest lies in “race in U.S. political culture 1790-present, including U.S. imperialism, immigration and migration, popular culture, and the juridical structures of U.S. citizenship” (“Matthew”). Seeing as Cohen's article is published in The Journal of American History, it is only fitting that his secondary sources match both the discipline of the journal, article, and author's education.

As stated in the previous paragraph, Cohen's secondary sources all relate to American expansion, imperialism, and globalization. The authors discussed above are the most cited, and therefore the most likely scholars that Cohen is having a 'conversation' with. The discussion of American expansion inevitably includes analysis of economic incentives and foreign relations. Rosenberg and LaFeber seem to support that American expansion was in effect incited by ideal economic conditions and motives (Group Notes). Other historians such as Ernest May “differed in [their] interpretation of the 1890s” from that of LaFeber (LaFeber). In fact, LaFeber's book The New Empire: An Interpretation of American Expansion 1860-1898 addresses May directly as 
Jensen 8

arguing that the "United States had 'greatness thrust upon it”” (LaFeber). Because Cohen fails to mention May in his article, one can only assume that this is a statement of uniting or contributing to LaFeber's side of the discussion in disagreement with May and other scholar's opinions. That being said, Cohen's contribution to the conversation is that of mixed review. Where Cohen is a strong supporter of economic incentives as significant cause to American expansion, he also addresses the controversial "weak state theory” (Cohen 372, n.4). Instead of disregarding the United States as a "weak state” during the $19^{\text {th }}$ century (Cohen 372, n.4), Cohen complicates this idea and suggests that the United States was not necessarily weak, but rather externally oriented: “a government that was not so much absent as it was defensive and outward facing” (Cohen 372). This is the notion of the "Outward State" Cohen offers as an alternative to the "weak state" theory (Cohen). By delving into the political motives of the international trade tariffs Cohen is rethinking economic expansion as a contributor to American imperialism and globalization. By reconsidering these fundamental theories of American history, Cohen is taking a stance on his impression of American economic expansion, American imperialism, and globalization and their contribution to America’s Outward State.

On each page of the article there are long lists of the abundant amount of sources Cohen uses to supplement his argument. The particularly prominent use of primary sources gives credibility to the evidence he presents to the reader. On occasion, Cohen will utilize two sources to support one example in the text, as on page 376, even furthering his credibility and gaining the trust of the reader. The use of direct quotes from sources is rare, which allows room for Cohen's own interpretation to slip into the article. Most often, Cohen will provide multiple examples from primary sources and then come to some sort of conclusion drawing inferences from the 
Jensen 9

data. One instance of this is after explaining the circumstances surrounding the H. B. Claflin and Company’s involvement in smuggling operation. Cohen uses this evidence to support his claim that by maintaining such steep taxes and tariffs on foreign goods the government was losing honest business men to the profitable business of smuggling (379). By presenting his primary evidence before presenting any interpretations Cohen is able to earn the trust of the reader since they have gone on the same journey he has in writing the article. Also, the level of control Cohen has over the sources is demonstrated well by the extended metaphor or conceit of the tariffs as a wall limiting international trade and globalization: "high walls separated America from the rest of the world” (373), “strong financial incentives encouraged Americans to scale the walls built around the nation's economy” (374), “compels the letting down of barriers by which a false political economy seeks to isolate nation from nation” (393).

The majority of the article employs credible use of sources like those mentioned above, but there are instances that lack sufficient evidence for the claim that is being made. The following example has two potential flaws. Memoirs provide a source of emotions during the time period but also come with a great possibility of bias. Nonetheless Cohen utilizes a memoir written by William H. Theobald, an agent of the United States Treasury, that compares his thoughts to those of Secret Service Chief Hiram Whitley on the subject of anti-Semitism: “Over time, the protests of Jewish leaders encouraged the elimination of overt bias if not an end to profiling. For instance, the 1875 memoirs of [Hiram Whitley] expressed vicious anti-Semitism, while the 1908 musings of [William Theobald] were far more circumspect” (395). However, as a critical reader I am skeptical as to how Cohen could have drawn this conclusion from the one source cited to the entire paragraph. Because there is only source used to support Cohen's claim, 
and it is a memoir, there is an increased possibility of skewed or misled information. Although Cohen's article is dense with evidence and quite thorough on the subject of smuggling, I still felt that the excessive amount of revenue made by the federal government was worth investigating as a possible incentive to maintain the tariffs. The excessive amount of money taken in by the federal government from taxes and fines is used to support some of Cohen's arguments but is never directly addressed and could enhance his argument concerning the neglect of domestic affairs.

During my study of this article, I found several similar themes between Cohen's theory and Karen Yamashita's novel The Tropic of Orange. Yamashita's mystical character, Arcangel, journeys from Mexico to Los Angeles, California to fight his arch nemesis, super villain "Supernafta” (Yamashita). "Supernafta” is an allusion to the North American Free Trade Agreement activated January 1, 1994 (“NAFTA”). This agreement amalgamated the United States, Canada, and Mexico in a free-trade zone permitting all three countries to trade with one another without import or export tariffs. However ideal this may seem to the reductionists, or free-trade advocates, of Cohen's article, several outcomes of NAFTA were and are crippling to Mexican consumers and producers (Whitbeck). The subsidies and oligopolies within Mexican, American, and Canadian economies have created the optimal environment for American businesses to maximize profits by taking advantage of cheap labor and production in Mexico (Carlsen). American businesses combine local inputs with American technology to set a price too low for local Mexican producers to compete with. The United States is entering foreign markets and stripping local producers of their opportunity to make a profit, unnervingly imperialistic and allusive to America's “Outward State.” The sectionalism and segregation 
created by trade blocks remain present, if not more prominent, under the North American Free Trade Agreement which Cohen condemns as economic trespass into foreign markets. Yamashita’s fight between Arcangel and Supernafta represents the epic struggle between Mexican producers and the exploitation of NAFTA. Where smugglers were resisting the government's monopoly on trade, the resistors of NAFTA are protesting American market manipulation. However, the unfair consequences of NAFTA are only one instance of American imperialism that Yamashita chooses to symbolize. Also prominent in her novel are conflicts unique to Asian-Americans that include attempts to smuggle and immigrate into the United States. Yamashita's novel is a close-up and personal account of the cultural and individual impacts of globalization while Cohen's article is a theory on where this behavior originated in American history. Both works foreshadow a future of negative externalities from globalization and focus specifically on inequities for those who do not fit the Anglo-American stereotype. 
Works Cited

Carlsen, Laura. “Americas Policy Report The Mexican Farmers' Movement: Exposing the Myths of Free Trade.” International Forum on Globalization. 25 Feb. 2003. 12 May 2011. <http://www.ifg.org/analysis/wto/cancun/mythtrade.htm>.

Cohen, Andrew W. “Smuggling, Globalization, and America's Outward State, 1870-1909.” The Journal of American History 97.2 (2010): 371-398. Oxford Journals. 29 Mar. 2011. <http://jah.oxfordjournals.org.proxy.lib.pdx.edu/content/97/2/371.full.pdf+html>.

---. The struggle for order: Law, labor, and resistance to the corporate ideal in Chicago, 19001940. Diss. The University of Chicago, 1999. Dissertations \& Theses: Full Text, ProQuest. 30 May. 2011.

---. Syracuse University. 10 Apr. 2011. <http://faculty.maxwell.syr.edu/aw cohen/Default.htm>. DuBois, Lori. "Harper's Weekly." Williams College Libraries. N.p,, 24 Jan. 2011. 18 May 2011. $<$ http://library.williams.edu/news/367/>.

“George Chauncey: Professor.” Yale University Department of History. 2007. 30 May 2011. <http://www.yale.edu/history/faculty/chauncey.html>.

“Group Notes: By Eric Chunn, Lindsey Green, Kate Jensen, and Lily Breshears.” May 17, 2011. Hoganson, Kristin. “Kristin Hoganson: Professor of History.” Department of History at Illinois. n.d. 12 May 2011. <http://www.history.illinois.edu/people/hoganson/>.

LaFeber, Walter. The New Empire: an interpretation of American expansion , 1860-1898. 35th. Ithaca, NY: Cornell University Press, 1963. Google. 9 May 2011. <http://books. google.com/books >. 
“Matthew Jacobson: Proffesor of American Studies and History.” Yale University Department of History. 2007. 12 May 2011. <http://www.yale.edu/history/faculty/jacobson.html>.

Mead, Walter R. Rev. of Blessed Among Nations: How the World Made America. Foreign Affairs. Council on Foreign Relation, Dec. 2006. 12 Apr. 2011. <http://www. foreignaffairs.com/articles/61989/walter-russell-mead/blessed-among-nations-how-theworld-made-america>.

“North American Free Trade Agreement (NAFTA).” Office of the United States Trade Representative. 2011. 12 May 2011. <http://www.ustr.gov/trade-agreements/free-tradeagreements/north-american-free-trade-agreement-nafta>.

“President's Distinguished Lecture Series: Walter LaFeber.” University of Vermont. 2003. 3 May 2011. <http://www.uvm.edu/ presdent/DLS/walterlafeber.html>.

Rauchway, Eric. “Eric Rauchway: Curriculum Vitae.” University of California, Davis. 2010. 12 Apr. 2011. <http://rauchway.ucdavis.edu/thisbethecv.pdf>.

Rosenberg, Emily. “Emily Rosenberg.” University of California Irving Department of History. n.d. 3 May 2011. <http://www.humanities.uci.edu/history/faculty_profile_ rosenberg.php>.

Whitbeck, Harris. “Mexican Farmers Protest NAFTA.” CNN. 1 Feb. 2008. 12 May 2011. <http://articles.cnn.com/2008-02-01/world/mexico.farmers_1_mexican-officialsmexican-government-nafta?_s=PM:WORLD>.

Yamashita, Karen T. Tropic of Orange. Minneapolis: Coffee House Press, 1997. 